\title{
The Form and Intensity of Community Participation in Conservation Management Program at Papua Barat Province
}

\author{
Yacob Fonataba ${ }^{1}$, Marlon I. Aipassa ${ }^{1}$, Sumaryono ${ }^{1}$, Simarangkir B.D.A.S ${ }^{1} \&$ Anton S. Sinery ${ }^{2}$ \\ ${ }^{1}$ University of Mulawarman, Samarinda, Indonesia \\ ${ }^{2}$ Center of Environmental Research, University of Papua, Manokwari, Indonesia \\ Correspondence: Anton S. Sinery, Center of Environmental Research, University of Papua, Manokwari Indonesia. \\ J1. Gunung Salju Amban Manokwari, Indonesia. Tel: 62-852-4430-8802. E-mail: anton_sineri@yahoo.com
}

\author{
Received: January 11, $2018 \quad$ Accepted: February 16, $2018 \quad$ Online Published: May 30, 2019 \\ doi:10.5539/eer.v9n1p41 URL: https://doi.org/10.5539/eer.v9n1p41
}

\begin{abstract}
This research aimed to determine the degree of participation of local communities in the management program of Gunung Meja natural recreation park and to provide alternative recomendations for the management based on community participation. Community participation in the management of the park was found to be the highest in the family group (46.15\%), and the lowest in the leader group $(5.13 \%)$. The same case was also found in the intensity of community participation. The participation of community includes leaders, interested groups, household heads, housewives and youth which was categorised as very inactive. This inactive result was influenced by community participation function which was in general only participating in activity implemention,information sharing and consultation. The management efforts were permit of natural tourism utilization and natural resources tourism infrastructure utilization, which can be used as the basis of the management program.
\end{abstract}

Keywords: participation, community, Natural Tourism Park

\section{Introduction}

Gunung Meja (GM) Forest is one of the Natural Tourism Parks (NTP) in the Province of Papua Barat as stipulated under the Indonesia Forestry Ministrial Decree No. 91 / Menhut-II / 2012 with an area of 462,16 Ha. This area is located at $16-177 \mathrm{~m}$ above sea level, is a natural laboratory that contains a high diversity of flora and fauna species and acts as a water reservoir for Manokwari city (Sinery, 2006; Lekitto, 2008, Manusawai and Leonard, 2015). A spatial survey conducted by WWF (2002), reported five water springs in this area. Whereas drinking water area company of Manokwari Regency reported there to be 12 springs which supply water to communities of Manokwari City. Seven if these springs are located within or adjacent to Gunung Meja Nutural Tourism Park (GMNTP) (Liborang, 2004). According to Manusawai and Leonard (2015) the GMNTP has 223 species of forest vegetation covering 159 tree-level species, 149 pole-level species, 164 sapling-level species and 177 seedlings-level species. Furthermore, the level of forest vegetation diversity is high (4.38) in tree-level, whereas at the seedling level it reaches 1.79 with medium category.

GMNTP is located in the middle of Manokwari City so it is easily accessible and prone to the utilization of natural resources and land conversion. According to Ohuiwutun (1995) as cited by Sinery (2006), forest degradation of GMNTP due to surrounding community activities had reached 8.9 ha. In addition Apriani (2003) stated that the utilization of GMNTP in 2002 amounted to 39.42 ha with an intensity of $8.6 \%$, including farming 35.32 ha (intensity $7.68 \%$ ), logging 0.81 ha (intensity $0.18 \%$ ), 0.34 ha of shifting cultivation (intensity $0.09 \%$ ) and other use 2.95 ha (intensity $0.64 \%$ ). This condition leads to degradation of forest areas that become the leading tourism potential and habitat fragmentation of various wildlife species. In addition, Kondororik (2012) reported that there are 30 sites of waste piles with a total pile area of 2,054 $\mathrm{m}^{2}$ or $0.2054 \mathrm{Ha}$. Moreover, Manusawai and Leonard (2015) indicated that there are five urban villages around GMNTP whose communities directly or indirectly affect the dynamics of this forest area. The influence was referred to shifting land use area from natural forests into gardens or open land.

Since its establishment, GMNTP has been officially managed by Natural Resources Conservation Center (BBKSDA) Papua Barat through Natural Resources Conservation Area (KSDA) Region II Manokwari. So far, efforts have been made regarding the protection, preservation and utilization of GMNTP area, however the threat 
to the existence of the region continues to grow. This is allegedly not only due to population growth but also due to management program that has not fully accommodated the interested groups, especially the communities. The condition is suspected to affect the level of participation of involved parties, in this case the local communities, in forest management activities.

The purpose of this research was to identify the level of community participation in GMNTP management program in order to aid the development of a more effective strategy that will support the success of GMNTP management based on local community participation.

\section{Method}

\subsection{Site Selection}

This research was conducted at Gunung Meja Tribal Natural Tourism Park Papua Barat Province during a 3 month period in April to June 2018.

\subsection{Research Equipment and Material}

A digital camera was used to document important objects in the field. A tape recorder/cellphone (HP) was used to record interviews with respondents to ensure no information was omitted. Stationeries such as calculators and computers for data processing and questionnaire to obtain primary data from respondents which are the main data to be analyzed, as well as maps and documents of previous research and various other reports relating to GMNTP, used as a source of secondary data and/or information.

\subsection{Metho, Technique and Research Variable}

This study utilized a descriptive methodology based on field observations and interview techniques to describe the condition of certain variables of interest. The research variables observed in this study consisted of management programs conducted by governing institutions, participating and non-participating communities and the function and intensity of community participation. Furthermore, the supporting variable in this research was the general condition of GMNTP area.

\subsection{Selection of Respondents}

Respondents were selected through "Stratified Sampling" by dividing the population into 5 strata based on demographics and community roles of the respondents, in accordance with the demands of data processing formulation. Two respondents from the "community leaders" group, 4 respondents from the interested group (forest farmer group), 18 respondents from the "household head" group, 8 respondents from the "women" group and 9 respondents from the "youth" group were interviewed.

\subsection{Data Collection}

Data collection was conducted using direct observations in the field, interviews based on a prepared questionaire and documentation of responses (data collection to obtain written data through books, drawings, photos to support data obtained through observation and questionnaires).

\subsection{Data Analysis}

Raw data was cleaned, edited and coded in order to clarify responses based on the respondent answers according to category. Response frequency was then calculated and tablulated. The assessment of the level of participation of local communities in the implementation of GMNTP management program was based on the multiplication of the index figures of actors, with the index number in terms of what and the index number of how participation (Table 1).

Table 1. Participation Index

\begin{tabular}{lcc}
\hline \multicolumn{1}{c}{ Communities } & Function & Intensity \\
\hline 5. Youth & 5. Management & 5. Supervision \\
4. Women & 4. Planning & 4. Do iniative actions \\
3. Housewife & 3. Implementation & 3. Decision making \\
2. Interest group & 2. Maintenance & 2. Provide consultation \\
1. Leaders & 1. Distribution & 1. Provide information \\
\hline
\end{tabular}

Source: Poli (1997) cited by Sinery dan Manusawai (2016)

Description: numbers $1,2,3,4,5$ are indexes. 
The highest number was 125 , the lowest was 1 , the scoring scale of the lowest to the highest score participation rate with 5 groups with the categories; very inactive, inactive, active enough, active, very active.

\section{Result and Discussion}

\subsection{The Function of Community Participation}

Based on the interview results with both community and management institution i.e. BBKSDA Papua Barat in this case KSDA Region II Manokwari, it was recognized that in the period of 2013 to 2017 (Early June 2018) there are seven programs or activities undertaken by the governing institution (BBKSDA Papua Barat) and/or partners including BPDAS Remu-Ransiki, Forestry Agency, Planning and Development Agency, Environmental Agency in district level, while in provincial level, the authors interview Forestry and Tourism Agencies, Universities, NGOs and communities. These activities include the construction of boundary fences, planting activity of MPTS, socialization activity (socialization of area functions and pioneers of mental revolution), regional monitoring activity and fire prevention training activity.

From a number of activities conducted, it was shown that the involvement of community in the management of GMNTP in the participation function, especially the participation of the community in the implementation of the management program conducted by BBKSDA Papua Barat through KSDA Region II Manokwari and KSDA partners influenced the community's evaluation of the impact of participation in the program as discussed in detail on the reasons people participated.

Table 2. Participation Function of communities of Ayambory Village in management program of GMNTP

\begin{tabular}{llll}
\hline \multirow{2}{*}{ No } & Form of Community Participation & \multicolumn{2}{c}{ Number of respondent } \\
\cline { 3 - 4 } & & Ayambori & $\begin{array}{l}\text { Percentage } \\
(\%)\end{array}$ \\
\hline 1 & Management & - & - \\
2. & Planning & 2 & 5,13 \\
3. & Implementation & 4 & 10,26 \\
$4 . \quad$ & Maintenance & 10 & 25,64 \\
$5 . \quad$ Distribution & 23 & 58,97 \\
\hline Number of respondents participated & 39 & 95,12 \\
\hline Number of respondents did not participate & 2 & 4,88 \\
\hline Amount & 41 & 100,00 \\
\hline
\end{tabular}

\section{Description:}

1. Participation in providing information, consultation, decision-making, initiating action, implementation, maintenance, monitoring and evaluation.

2. Participation in program management, especially planning of MPTS planting activity and installation of fence.

3. Participation in the program of Planting MPTS activity and the construction of boundaries fence.

4. Participation in supporting the success of the program, especially the monitoring activity (routine patrol).

5. Users of regional management programs, especially fire prevention training and socialization activities.

The data as shown in Table. 2 indicate that not all respondents interviewed participated in the implementation of GMNTP management program. The result confirmed a clear difference when compared with other research of Mulyadi (2005), Sinery and Manusawai (2016) or Fonataba et al (2018). According to Mulyadi (2005), 100 out of 118 respondents $(84.74 \%)$ interviewed participated in the management of conservation programs of Bukit Soeharto Education Forest and Research (HPBBS). Furthermore, Sinery and Manusawai (2016) stated that only 41 respondents (34.7\%) participated in the management of Wosi Rendani Protected forest and the remaining 77 respondents (65.3\%) did not parcipate. In contrast to Fonataba et al (2018) who mentioned that the community in Sorong Nature Tourism Park $100 \%$ participated in the management program conducted by the managers and partners because of the status of this community which was forest community group in addition to the value of the benefits of participation which is related to the family economy.

The results show that the participation of Ayambori Village community in GMNTP management was based on the highest participation function in the program/user distribution - 23 respondents $(58.97 \%)$. The function was seen 
in the implementation of fire prevention training and socialization activities, both the socialization of the function of the area and related to the increase of community understanding of environmental tranquility. Likewise, the maintenance function in the area security program through area monitoring (routine patrol) with 10 respondents (25.64\%). Implementation function realized in the form of MPTS planting activities and construction of border area with the number of respondents as many as 4 people (10.26\%) and the function of planning through siterelated planning activities and labor in MPTS planting activities and construction of fences area limits with the number of respondents as many as 2 people $(5.13 \%)$. The function of planning referred to in this context is the involvement of the community in determining the location of planting, selection of plant species, determining the boundary location of the construction of fences and labor. Moreover, the management function is not identified / encountered which is similar to the findings identified in community participation in the management of conservation programs of Forest Education and Research Bukit Soeharto (Mulyadi, 2005) or community participation in the management of Sorong NTP (Fonataba et al, 2018).

The function of community participation in the management of GMNTP was concentrated in program user distribution, especially fire prevention and socialization activities which indicate the form of community participation function in the management of the program similar to the participation of the community in the management of protected forest of Wosi Rendani which had showed the concentration of respondents on the function of distribution and implementation (Sinery and Manusawai, 2016). This was preseumably related to the focus of management activities that are not the location of program implementation and the condition of the community was not formed due to the interest of the business/activity like the forest farmer group, so that the management of the program was more even and involves all the members of the farmer group. According to Fonataba et al (2018) the forest farmers group of Matoa in Klasaman Village was a community formed because of similar interest in management programs that were generally built from a joint planning to implementation and even to the joint evaluation of the governing institution.

The characteristics of the community were also assumed to affect participation, where the people of Ayambori village were local comunity who were generally from the Arfak tribe, so they have the same natural resource management character (limited to participating in the implementation program nevertheless not in planning the program). The condition was added by the absence of harmonization of management planning activities among related stakeholders regarding the management of GMNTP. Besides GMNTP was not the focus of management activities, especially the community empowerment as directed by the Directorate General Conservation of Natural Resources and Ecosystem (KSDAE) of the Ministry of Environment and Forestry (KLHK) in 2017. Along with Sallatang (1987) in the implementation of development projects, at the stage of implementation relatively communities participate actively in various forms, including the important ones were; follow lighting, become participants of the object and took advantage of economic benefits.Usually the number of participating citizens was not sufficient. On the other hand, at the planning and assessment stage, generally community members are unlikely to participate with the reason that they were excluded.

Table 3. Intensity of Community Participation in GMNTP Management Program

\begin{tabular}{llll}
\hline No & Form of community participation & Number of respondent & $\begin{array}{l}\text { Percentage } \\
(\%)\end{array}$ \\
\hline $1 . \quad$ Total control & 0 & 0,00 \\
2. $\quad$ initiate the implementation of activities & 2 & 5,13 \\
3. $\quad$ Decision making & 4 & 10,26 \\
$4 . \quad$ Provide consultation & 18 & 46,15 \\
$5 \quad$ Provide informasi & 15 & 38,46 \\
\hline Number of respondent participated & 39 & 95,12 \\
\hline Number of respondent did not participate & 2 & 4,88 \\
\hline Amount & 41 & 100,00 \\
\hline
\end{tabular}

Description:

1. Total control was the participation of community elements in various forms of activities for the success of the program.

2. Initiate action was the participation of community elements in the form of initiative actions for the implementation of the management program 
3. Decision-making was the participation of community elements in determining what should be done in the program

4. Providing consultation was the participation of community elements in solving the problems that arise with respect to the management program

5. Providing information was the participation of community elements in the delivery of information both orally and written, on matters relating to the management program;

Table 3 indicates that the intencity of community particpation in the management of GMNTP was not equal across all forms of participation. In particular, the form of total control as found in the form of community participation in the management of Sorong Natural Tourism Park (Fonataba et al, 2018). The highest intensity of participation in management programs of GMNTP was in providing consultation services with as many as 18 respondents (46.15\%), followed by providing information with 15 respondents $(38,46 \%)$, decision making (community participation in decision making such as determination of plant species, planting site of MPTS, fence area) with 4 respondents $(10,26 \%)$. The lowest intensity of community participation with 2 respondents $(5,13 \%)$ is in the form of initiate action. There were 2 respondents $(4.88 \%)$ out of 41 interviewed that did not participate in the management program, either by function or intensity. The two non-participating respondents were classified as school youth group at Junior High School and because of their routine as school children, so that at the time of program implementation they did not have time to be involved.

The form of community participation in the intensity of participation was distributed on providing consultation. This indicated that although there was no community in the intensity of total control participation, but in the implementation of the management program there were already some communities that seek to participate by providing consultation and information related to the condition and potential of the region. This was appreciated by the participation of the community in monitoring activities (routine patrol) and socialization by providing consultation related to program and information on position and condition of boundary, encroachment site and other sites.

This condition was similar to community participation in the management of protected forest of Wosi Rendani. In contrast to the intensity of community participation in the Forest Education and Research Bukit Soeharto (Mulyadi, 2005) and/or community participation in the management of Sorong NTP (Fonataba et al, 2018), which actually has similarities in terms of implementation of management programs when compared with program management in protected forests of Wosi Rendani (Sinery and Manusawai, 2016). This was influenced by the characteristics of the community formed as a farmer community in government administration, as well as the focus of program implementation that does not cover GMNTP area.

\subsection{Function and Intensity of Participation by Community}

Table 4. Function and Intensity of Community Group Participation in the management of GMNTP

\begin{tabular}{lllllll}
\hline \multirow{2}{*}{ Form of parrticipation } & \multicolumn{2}{l}{ Respondent } & & \\
\cline { 2 - 7 } & Leader & Interest group & Household head & Housewife & youth & Amount \\
\hline Management & - & - & - & - & - & - \\
Planning & 2 & - & - & - & - & 2 \\
Implementation & - & 2 & 2 & - & - & 4 \\
Mainantenance & - & 2 & 8 & - & - & 10 \\
Distribution & - & - & 8 & 8 & 7 & 23 \\
\hline Amount & 2 & 4 & 18 & 20,51 & 17,95 & 100,00 \\
\hline Percentage (\%) & 5,13 & 10,26 & 46,15 & - & - & 0 \\
\hline Total Control & - & - & - & - & - & 2 \\
Initiate Action & - & 2 & - & - & - & 4 \\
Decision Making & 2 & 2 & - & 8 & - & 18 \\
Consultation & - & - & 18 & 8 & 7 & 15 \\
Informing & - & - & - & 18 & 20,51 & 17,95 \\
\hline Amount & 2 & 4 & 46,15 & 100,00 \\
\hline Percentage (\%) & 5,13 & 10,26 & & & 79 \\
\hline
\end{tabular}

Table 4 confirms that the participation of community groups in the management of GMNTP is highest in the 
household head group consisting of 18 respondents (or 46.15\%). The lowest is the leader group comprising 2 respondents (or 5.13\%). These conditions illustrated that household head group was the group that participate the most in the management program compared with other community groups. The data also indirectly explained the number of respondents who were positively correlated with the form of participation although the quantity does not show a positive correlation between the groups of comunity, the function and the intensity of participation. According to Sinery and Manusawai (2016) each household head has different functions and roles that will provide different responses to innovations or programs, although the general hierarchy in community has largely depicted the roles and functions of community groups.

This condition clarified that in both the function and intencity of community participation, household head group was the group that participated at the highest level in the management of GMNTP. This shows normal conditions in the social stratification of the community. According to Sardjono (2004) household group in this case the household head was the first household member received the innovation and will be involved in the management of innovation. According to Sinery (2015), Sinery and Manusawai (2016), although there are differences in access to natural resources, the household head was the mainstay of the community in accepting an innovation / program / activity which was further implemented. Furthermore, this condition becomes community characters which still rely on natural resources.

\subsection{Level of Participation and Perceptions of Community Groups}

Table 3 showed that in function of participation, the number of leaders to participate was 2 respondents (100\%) which was similar to the intensity of participation which was also 2 respondents $(100 \%)$ in the form of decisionmaking. If tabulated in the "Participation Empowerment Index" table, the participation level of leader is $1 \times 4 \times$ $3=12$ indicating that the participation of the leader in the GMNTP management program was grouped to the category of "very inactive" (in the range of $1-25$ ).

Function of community participation of interest group in GMNTP management program was 2 respondents (50\%) in "program implementation" and 2 respondents (50\%) in "maintenance". Furthermore, the intensity of community participation of the interest group as many as 2 respondents (50\%) on "initiating activity" and 2 respondents (50\%) on "decision-making". If tabulated in the "Participation Empowerment Index" table, the participation level of interest group is $2 \times 3 \times 4=24$ and $2 \times 2 \times 3=12$ which indicated that community participation of interest element in TWA Gunung Tabel management program falls into the category of "very inactive" (in the range of values 1 25).

Function of community participation of household head in GMNTP management program was 2 respondents (11.1\%) in "program implementation", 8 respondents (44.4\%) in "maintenance" and 8 respondents (44.4\%) in "distribution". Likewise, the intensity of community participation of household head group as a whole was 18 respondents (100\%) at "provide consultation". If tabulated in the Participation Empowerment Index table, it was found that the community participation level of household head group is $3 \times 3 \times 2=18$ or $3 \times 2 \times 2=12$ or $3 \times 1$ x $2=6$, hence the community participation of the household head group in GMNTP management program was categorized to be "very inactive" category (in the range of values $1-25$ ).

Function of community participation of housewife in GMNTP management program was 8 respondents (100\%) in "distribution", while the intencity of participation intensity was also 8 respondents $(100 \%)$ on "provide information". If tabulated in the Participation Empowerment Index table, the participation level of housewife group is $4 \times 1 \times 1=4$, consequently that the participation level of housewife group can be categorized as "very inactive" (in the range of $1-25$ ).

Participation function of youth group in GMNTP management program was 7 respondents (100\%) in "distribution". Additionally, at the intensity of participation as many as 7 respondents $(100 \%)$ on "provide information". If tabulated in the Participation Empowerment Index table, it was found that the participation rate of youth group is $4 \times 1 \times 1=4$, thus the participation of youth group in the GMNTP management program was included into "very inactive" category (in the range of $1-25$ ).

Overall, level of community participation in the management of GMNTP was very inactive for all groups within the community. In the management perspective, the condition will affect the minimum achievement of management objectives and may even lead to failure. According to Margiono (1999), all groups of community should be actively involved in every process of development implementation because without active involvement of communities, the success and sustainability of development program will be unattainable, it may even cause problems and potential failure for development itself. In line with Sinery and Manusawai (2016) ideal conditions expected in program management through collaborative management was active until very active because the conditions describe the empowerment of each comunity group to the program. 


\section{Conclusion}

Community participation in GMNTP included groups of leader, interest, household head, housewife and youth with very inactive participation levels that were influenced by function of community participation mainly in the form of implementation while the intensity of community participation mainly in providing consultation and information.

Management efforts include efforts to create Business License for Utilization of Nature Tourism Services (IUPJWA) and Business License for Utilization of Nature Tourism Facility (IUPSWA) to become the basis for program management; community involvement in planning, maintenance, management, decision making, initiative action and program control; increasing the frequency of socialization and counseling that can provide insight to the community about the economic and ecological meaning of the results of the management program and to pursue community economic improvement programs through the provision of vegetable seeds and MPTS plant seeds.

\section{Acknowledgement}

The authors wishes local community in GMNTP, who assisted during field data collection. Special thanks is also extended to those who contributed to the research and writing of this article.

\section{References}

Apriani, S. (2003). Intensitas Penggunaan Lahan Oleh Masyarakat Pada Hutan Wisata Gunung Meja. Skripsi Sarjana Kehutanan Fakultas Kehutanan Universitas Papua, Manokwari.

Fonataba, Y., Aipassa, M. I., Simarangkir, B. D. A. S., Sumaryono, M. J., Manusawai, V. F., \& Anton, S. S. (2018). Community Participation in the Management of Sorong Nature Tourism Park, Sorong City. Energy and Environment Research, 8(1), 48-55.

Kondororik, M. (2012). Karakteristik Sampah Padat Dan Nilai Ekonomi Degradasi Lingkungan Akibat Sampah Pada Kawasan Taman Wisata Alam Gunung Meja Manokwari. Tesis Magister Ilmu Lingkungan Universitas Papua.

Liborang, A. S. T. (2004). Debit Air Pada Tujuh Mata Air di Sekitar Kawasan Hutan Wisata Gunung Meja Kabupaten Manokwari. Skripsi Sarjana Kehutanan Universitas Papua, Manokwari.

Mulyadi, F. (2005). Partisipasi Masyarakat Lokal Dalam Upaya Konservasi Di Hutan Penelitian Dan Pendidikan Bukit Soeharto. Tesis Magister Ilmu Kehutanan Universitas Mulawarman, Samarinda.

Sallatang, M. A. (1987). Faktor-Faktor yang Menghambat Partisipasi Masyarakat Dalam Pembangunan di Sulawesi Tengah. Lembaga Penelitian Universitas Hasanuddin, Makasar.

Sardjono, M. A. (2004). Mosaik Sosiologis Kehutanan: Masyarakat Lokal, Politik dan Kelestarian Sumber Daya. Debut Press, Jogyakarta.

Sinery, A. (2006). Species of Cuscus in Taman Wisata Gunung Meja Manokwari Regency, West Irian Jaya. Biodiversitas, 7(2), 175-180.

Sinery, A. (2015). Strategi Pengelolaan Kuskus di Pulau Numfor. Deepublish, Yogyakarta.

Sinery, A. S., \& Manusawai, J. (2016). Community Participation of Management Program in The Wosi Rendani Protected Forest. Journal Manusia Dan Lingkungan, 23(3), 394-401.

\section{Copyrights}

Copyright for this article is retained by the author(s), with first publication rights granted to the journal.

This is an open-access article distributed under the terms and conditions of the Creative Commons Attribution license (http://creativecommons.org/licenses/by/4.0/). 